\title{
The Victorian Age and the Other
}

\author{
Andreea Bălan
}

\author{
Department of English Literature, University of Craiova, Romania \\ Email: balan.andreea95@yahoo.com
}

Received: 30 Jan 2021; Received in revised form: 25 Apr 2021; Accepted: 10 May 2021

(C2021 The Author(s). Published by TheShillonga. This is an open access article under the CC BY license (https://creativecommons.org/licenses/by/4.0/)

\begin{abstract}
This paper deals with the reception of the Other in Queen Victoria's realm - where the sun never sets. Covering an enormous surface of the known world, the Empire triggered real answers to the presence of the subjects of the worldwide British Empire in good ole' England. Literary representations of the Other appeared in every genre, but especially in the novel, which more than any other literary form of the period attempted to analyze and represent Victorian socio-political stratification. Critics have usefully examined the novelistic representations of each form of Otherness, considering, for instance, representations of the "Oriental," the "African," the "Indian," the "Irish," the "Jew," or the "Scot." As we will see, while Victorians attempted to relate different kinds of Otherness to one another, they made both tremendous and subtle distinctions between different marginalized groups.
\end{abstract}

Keywords-otherness, postcolonial theory, the Victorian era.

\section{INTRODUCTION}

The Victorian Era is frequently referred to as the Age of Empire. Throughout Queen Victoria's lengthy reign, Britain extended its territorial and colonial holdings, building an empire on which the sun never set. The Victorian Era witnessed Britain change itself from an agricultural kingdom to a significant industrial power. The territory changed as thousands of miles of railroad track were designed, reducing journeys that had once taken days by foot or horse into a few hours' duration.

On the academic level, the 19th century saw the overlapping of Romanticism and Victorianism, and the presence of Darwin who challenged long-established theories regarding the evolution of humankind. "The Century of the Novel", as it was called, addressed itself to specific readers which - in order to be included into this category - had full access to the printed text. This access was aided by the publishing policies of the age which fully responded to the demands of the reading public. The 19th century was undoubtedly the great age of the English novel, to which Henry James applied an enduring definition: "an intricately inwrought aesthetic and psychological design, and a subtle balancing of formal and moral tensions" [1].

We are here considering the development of the British Empire during the reign of Queen Victoria - a culmination of the centuries-long British policy of colonising the world - which involved "settlement, governing indigenous peoples, exploiting and developing the resources of the land, and embedding imperial government" [2]. In this situation, we are dealing with a literature composed by writers living during the colonial rule. Wisker is even more exact when she differentiates between colonial and colonialist literature:

"Colonial literature is that produced under colonial rule, by both the settlers and the indigenous people, while colonialist literature is that supporting colonial rule, springing from the viewpoint of colonialists, those supporting imperialism" [2]. Vijay Mishra and Bob Hodge believe that colonialism was felt differently in different parts of the world, an observation which is also important to the Victorians' own understanding of their world: 
"In the Indian subcontinent the colonial experience seems to have affected the cities only; in Africa it worked hand in hand with evangelical Christianity; in Southeast Asia the use of migrant labour - notably Chinese and Indian - mediated between the British and the Malays. In the West Indies slave labour, and later Indentured Indian labour, again made the relationship less combative and more accommodating" [3].

As Gina Wisker stated, postcolonial writing means "writing which resists colonialism and its power politics, produced both during, and, mainly, after the colonial period" [2]. Stephen Slemon thinks postcolonialism refers to a set of anti-colonial cultural practices, attitudes and behaviours: "it [postcolonialism] locates specifically anti or postcolonial discursive purchase to culture, one which begins in the moment that colonial power inscribes itself onto the body and space of its Others and which continues as an often occulted tradition into the modern theatre of the new-colonialist relations" [4]. Postcolonial literature prospers in a case which, in the beginning, involved oppression and resistance, anger and victimization, and in which, now, the common language sets a bridge between cultures - just as Rushdie's comma. Máire ní Fhlathúin is convinced that Britain was influenced - socially and politically - by the fall of the British Empire, triggering an intensive exodus of settlers of British colonies and former colonies to Britain after WWII. This wave of immigration:

... was met with a hostile response from many of the indigenous inhabitants, their fear of economic competition compounded by their long-established sense of the racial superiority of white people. The legal right to citizenship was eroded and then removed by further legislation, but not before many immigrant communities had become established in British cities. Their continued presence and their contribution to the cultural life of an increasingly multicultural country, serve as a reminder of Britain's imperial past [5].

In such a multi-ethnic community, racist perspectives manifested themselves from top to bottom, from the top ruling group down to the working populations, with each group feeling superior to those who had lower status. In Michel de Certeau's words, "every story is a travel story, a spatial practice' and the vehicle of this traverse in space and means of organizing places are 'metaphors."' Stories "carry out a labour that constantly transforms places into spaces or spaces into places" [6]. Stories have represented a significant part in the "formation of myths; however, they also have the capacity to challenge boundaries set by those myths and engage in the process of demythologization" [6].

Consequently, postcolonial narratives contribute to the demythologizing of the grand narrative of colonialism. This unexpected approach to place in literature is consonant with contemporary approaches to geography. According to Gillian Rose, "everyday experience of fragmentation and dispersal' requires intellectuals and critics to reconsider geography as fragmented and un-fixed." [7] Also, "white masculine ideology of a polarized geography should be replaced with the idea of geography as uncertain, multiple and diverse." [7] We can assume that in the particular instance of postcolonial literature places are informed by the situational complexity as well as the shared experience of systematic implementation of racial, gender, and geographical boundaries. Colonisation gave empire what Elleke Boehmer calls an 'intertextual milieu', indicating that it created cultural symbols that displayed a striking synonymity [8].

\section{THE VICTORIAN OTHER}

Otherness is inevitably represented by difference, connecting it predominantly with marginalized people, who are rejected from the dominant group, who are disempowered, quieted, separated due to various deviations or to social, religious, political and sexual differences. The preoccupation and fascination with the Other can be traced back to the beginning of human history and thought. As Simone de Beauvoir underlines, "the category of the Other is as primordial as consciousness itself. In the most primitive societies, in the most ancient mythologies, one finds the expression of a duality - that of the Self and the Other. [...] Otherness is a fundamental category of human thought" [9]. Four hundred years earlier, in his Essay "On the inconstancy of Our Actions", Michel de Montaigne remarked that the Other is not necessarily the antonym of the self but also part of what determines or even constitutes the self: "We are entirely made up of bits and pieces, woven together so diversely and so shapelessly that each one of them pulls its own way at every moment. And there is as much difference between us and ourselves as there is between us and our people" [10].

The notion that the self requires an Other to be complete and to understand itself has been revealed by many philosophers, psychoanalysts, sociologists, 
anthropologists and writers of all times. The origins of the word 'otherness' (and its ambiguous use) seem to have been introduced at the beginning of the nineteenth century by the German philosopher Georg Wilhelm Friedrich Hegel who was among the first to consider the other a constituent in self-consciousness: "Each uses the other as the means by which it achieves self-consciousness. This initially takes the form of desiring the death of the other" [11]. Moreover, he emphasizes the separateness between self and (an)Other, the alienation created between the two.

The notion is also used extensively in existential philosophy and in psychoanalysis. Jean-Paul Sartre's character Garcin, in the play Huis clos (No Exit, published in 1944) states that "L'enfer, c'est les Autres" [12]. Simone de Beauvoir draws attention to the fact that women have been 'othered': “...she is defined and differentiated with reference to man and not he with reference to her; she is the incidental, the inessential as opposed to the essential. He is the Subject, he is the Absolute - she is the Other" [9].

Finally, postcolonial theories, employ the term 'otherness' interchangeably with 'difference' and 'othering' in connection to race (Franz Fanon, Chinua Achebe, Abdul JanMohammed), natives (Homi Bhabha), women, multiculturalism and minorities, the politics of identity and representation (Edward Said), and when interrogating alterity (Gayatri Chakravorty Spivak, Sara Suleri). The process of othering has also been used to recognize differences and to distance the Self from the Other which may cause exclusion or marginalization from the group. The result may be a creation of stereotypical images, or multi-generational hatred and violence. Yet, acknowledging otherness has more positive than adverse outcomes: national identities are preserved, the 'silent' and effaced Other has made claims to speak (women, natives, minorities, deviants, subalterns are able to speak for themselves) reorganizing the world order in radical ways. Pia Brînzeu observes that difference becomes possible when combining "involvement with detachment", when adapting "the images of otherness to suit self-images, completing the more frequent stereotypes of the natives with a new set of attitudes brought from abroad" [13]. The articulation of otherness is possible "in concordance with social or minority perspectives, with the on-going negotiations that seek to authorize cultural hybridities, with the persistence and/or re-invention of tradition, the restaging of the past, and the consensual or conflictual engagements of cultural difference" [13].

According to Abdul R. JanMohamed, "genuine and thorough comprehension of Otherness is possible only if the self can somehow negate or at least severely bracket the values, assumptions and ideologies of his culture" [14]. He states that such a negation or 'bracketing' is impossible due to the fact that people are culturally formed and they cannot negate themselves. Even if narratives unusually change the way the Other is perceived, they often attract attention to the ones that are neglected, silenced or exploited. Literature is the means to designate the Other, to find the answer to the question who the Other is nowadays. Ania Loomba thinks that there is an interest in recovering the Other ("recovering subaltern voices") and in reconciling it with the Self because we are "invested in changing power relations" [15]. Therefore, if subaltern voices are to be heard and listened to "we need to uncover the multiplicity of narratives that were hidden by the grand narratives, but we still need to think about how the former are woven together" [15].

Jacques Lacan differentiated between the 'Other' and the 'other'; the other designates someone who resembles the self, such as the colonized people who are identified as the periphery that is different from the centre. The Other is the great Other, in whose gaze the subject gains identity. Emmanuel Lévinas also claimed that the Self cannot exist without the Other and, furthermore, the value of the Other must exceed the value of the Self: "In ethics, the other's right to exist has primacy over my own, a primacy epitomized in the ethical edict: you shall not kill, you shall not jeopardize the life of the other" [16]. Conversely, the Other also requires the Self to redefine its existence. When referring to the concepts of Self and Other, Lévinas also speaks of "uniqueness" in order to express the "otherness of the other. The unique is the other in an eminent way: he doesn't belong to a genus or doesn't remain within his genus" [16].

Jean Baudrillard declared the beginning of "an era of production of the Other". The Other will no longer be killed, devoured, seduced, faced, loved or hated, it will be produced. In any case, "otherness is lacking and, since we cannot experience otherness as destiny, one must produce the other as difference." [17] Likewise, Kwame Anthony Appiah worries about a possible "manufacture of otherness" for "those who will not see themselves as Other" [18]. Appiah also signals the dangers of raising awareness about the issues of identity and difference. In order to escape the label of 'Other', he appeals to nativism, that is viewing nations as 'organic communities', "bound together by [...] the shared norms that are the legacy of tradition, struggling to throw off the shackles of alien modes of life and thought" [18]. 


\section{THE GYPSY AS THE OTHER}

In the second half of the nineteenth century, commentators have written much on Gypsies in general, Gypsies in Britain, and even Gypsies in literature. Under the influences of the relatively new fields of anthropology, ethnology, and philology and the enthusiasm of the Romany Rais, scholars from the midnineteenth to the early twentieth centuries were eagerly attempting to fix the Gypsies' geographic origins, record and understand their language, and trace their migrations and their history. Their appearance triggered conflicting feelings of both fear and fascination. We are aware of a romanticized view of Gypsies, which manifests itself in works of fiction by many other authors throughout the Victorian Era. Renowned Gypsy appearances in Victorian literature are to be found not only in the already mentioned novels Jane Eyre (1847) and Wuthering Heights (1847), but also in Matthew Arnold's poem The Scholar Gypsy (1853), George Eliot's narrative poem The Spanish Gypsy(1864-1868), and Elizabeth Barrett Browning's novel written in verse, Aurora Leigh (1856). The gypsy motif in Jane Eyre reflects the ambiguous attitude of Victorian society toward Gypsies. The depiction of "the Gypsy" at Thornfield Hall and the characters' reactions to her reflect prejudices based on the Gypsies' skin color, way of life, and traditions and reflections of discriminatory treatment Gypsies suffered.

George Eliot herself devotes a full chapter to the protagonist's encounter with a Gypsy family in her novel The Mill on the Floss (1856), in which Maggie runs away to a Gypsy encampment, whose Gypsy Queen she hopes to become. Other nineteenth-century scholars and writers, both in England and North America, wrote treatises on the life and customs of the Gypsies, adding to the general interest. Moreover, the Gypsy Lore Society was founded in 1888 with the purpose of collecting and preserving the cultural artefacts of Gypsy life. Writing about the Gypsy presence in Britain, Deborah Epstein Nord thinks that, "unlike colonial subjects, however, Gypsies were a domestic or an internal other, and their proximity and visibility were crucial features in their deployment as literary or symbolic figures" [18].

\section{CONCLUSION}

By relating the characteristics of these representations to one another, such critics have begun to develop what might be called "a unified field theory" of Otherness, describing how each such representation functions in a larger Victorian project: the project of disciplining the conceptual borders of the nation-state. At the same time, such criticism has sought to avoid the assumption that, for the Victorians, all forms of Otherness could be reduced to a fixed collection of stereotyped traits.

\section{REFERENCES}

[1] James, H. Our Mutual Friend in Nation 1 (December 1865): 786-87. Reprinted as "The Limitations of Dickens" in Views and Reviews, Boston, Ball, 1908 pp. 786-87

[2] Wisker, Gina. Post-Colonial and African American Women's Writing, London, Macmillan Press Ltd. 2000, p.3-5.

[3] Vijay Mishra and Bob Hodge in Chrisman and Williams. Colonial Discourse and Post-Colonial Theory, London, Routledge. 1994, p. 282.

[4] Slemon, Stephen. Modernism's Last Post, in Adam and Tiffin, 1991, p.3.

[5] Máire ní, Fhlathúin. The British Empire, in John McLeod, The Routledge Companion to Postcolonial Studies, New York, Routledge, 2007, p.31.

[6] De Certeau, Michel. The Practice of Everyday Life, trans. Steven Rendall, Berkeley, CA:University of California Press, 1988, p.118, p.126.

[7] Rose, Gillian. Feminism and Geography. London: Polity Press, 1993, p.159.

[8] Boehmer, Ekkehart. Abfassungszeit des Guillaume de Palerne, Romanische Studien, 1878, p.52.

[9] De Beauvoir, Simone. The Second Sex. Introduction in W. McNeill, K. Feldman (eds.) Continental Philosophy: An Anthology, Oxford, Blackwell, 1998, p.161.

[10] Michel de Montaigne, Essays II:1, transl. M. A. Screech, The Complete Essays, Penguin, 1991, p. 380.

[11] Hegel, Friedrich. Phenomenology of Spirit (trans. by A. V. Miller), Delhi, Motilal Banarsidass 1998, p. 521.

[12] Sartre, Jean-Paul. Huis Clos, New York, Routledge, 2000, p.95.

[13] Brînzeu, Pia. Postcolonialism or Postcolonialisms?: The Dilemmas of a Teacher in British and American Studies, vol. XIV, Timişoara, Editura Universităţii de Vest, 2008, pp. 25, 27.

[14] Abdul, JanMohamed's. The Economy of Manichean Allegory: The Function of Racial Difference in Colonialist Literature. The University of Chicago Press, 1988, p.84

[15] Loomba, A. Colonialism/ Post-colonialism. London and New York: Routledge. 1998, p. 243, p. 241. 
[16]Levinas, Emmanuel. Ethics of the infinite in R. Kearney States of Mind. Dialogues with Contemporary Thinkers on the European Mind, 1995, p. 189, p.177.

[17]BAUDRILLARD, J., M. Guillaume. Figuri ale alterităţii (Paralela 45: Piteşti: Paralela 45, 2002), p.127. Available in English at http://www.egs.edu/faculty/jeanbaudrillard/articles/plastic-surgery-for-the-other/) Accessed 20.04.2021

[18]Appiah, Kwame Anthony. In My Father's House: Africa in the Philosophy of Culture. Oxford University Press, 1993, p.156-7, p. 72.

[19]NORD, Deborah Epstein. Gypsies and the British Imagination, 1807-1930 (New York: Columbia University Press, 2006, p.3. 